\title{
Vigésimo aniversario de nuestra Facultad de Humanidades y Ciencias
}

María Cristina Caballero ${ }^{(1)}$

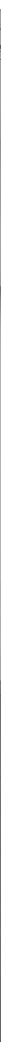

(1) Secretaria Administrativa

de la FHUC.-UNL 
La Facultad de Formación Docente en Ciencias estrenó su futuro acompañada de una comunidad fervorosa, cargada de sueños de expansión; reconocida por sus propulsores en su trayectoria de Escuela, como un ave pronta a desplegar sus alas en pos de un recorrido de grandeza que hoy pueden atestiguar sus seguidores.

La comunidad que atesoraba su basamento, liderada por un visionario surgido de sus entrañas, de esfuerzos irrenunciables, que teñía la lucha de cada día con el estigma de la camaradería, compartía almuerzos frugales y cenas extendidas rodeado por el personal, haciendo de cada celebración el encuentro oportuno para la transmisión del sentir y pensar de sus miembros.

Los siempre presentes Mauricio Epelbaum y sus directos colaboradores administrativos, Elvio Díaz, Oscar Lossio y Daniel Galetto, junto a inolvidables docentes, se hallan incólumes en el recuerdo de los que compartimos la hazaña de crecer con la institución.

Así transcurrieron aquellos días afanosos concebidos en un ambiente de familiaridad, donde el andamiaje de la educación, la ciencia y la tecnología iban estrechando los espacios físicos, lo que motivó la idea de desamarrar la cuna que dio vida a la institución enclavada en el seno de la ciudad, para soñar con horizontes más naturales, donde la simbiosis hace que el silencio dé paso al pensamiento permitiendo la supremacía del conocimiento.

Ávidos de emprender el atractivo desafío de crecer, los no docentes nos aprestamos al cambio adquiriendo nuevo saber o profundizando el tecnicismo a fin de lograr acompasadamente el reto.

Este transitar nos llevó con la mochila cargada de nostalgia a traspasar las puertas de la ciudad universitaria, que ofrecía un escenario para multitudes con cabida a la expansión, la que dio sus frutos en el 2000 al concebir la realidad de hoy "Facultad de Humanidades y Ciencias" que nos enorgullece con su fuerte presencia en el ámbito universitario santafesino y trascendente proyección social en vastas zonas de nuestro querido país. 